\title{
Le Rire de Candide: Voltaire and Bergsonian Comedy
}

\section{Annelie FITZGERALD}

torytelling and laughter are intimately associated in Voltaire's mind, as is suggested by the comedy which pervades Candide, and as rendered explicit in the emblematic relationship between Baron 人 Thunder-ten-tronck and his domestic staff: "Ils l'appelaient tous Monseigneur, et ils riaient quand il faisait des contes"(119). 'Indeed, it is generally acknowledged that Candide is a comic masterpiece. ${ }^{2}$ Nevertheless, or perhaps consequently, a comprehensive inventory and analysis of the myriad comic techniques employed by Voltaire in his most famous conte philosophique is an undertaking doomed to inadequacy (and one which would doubtless hardly constitute interesting reading). In any case, it certainly lies beyond the scope of this study in which I merely hope to show that Henri Bergson's theory of comedy can be applied in a relevant way to an analysis of comedy in Candide. I attempt to do so in full awareness of the potentially comic result, in Bergson's own terms, of imposing what are inevitably restrictive interpretations on the plenitude of a 'living' literary text, just as Candide warns us against applying systematic theories to the infinite diversity of human experience. ${ }^{3}$ I hope, however, that any insights my analysis might provide will outweigh its unavoidable shortcomings.

Jean Sareil is right to assert that "Candide est d'abord une joyeuse et furieuse satire" (ESC 41). Indeed, Voltaire's attacks on all manner of social 
injustices from within his fiction lead Sareil to conclude that "jamais il n'y eut de rire si engagé que celui de Voltaire" (ESC 100). Voltaire's satirical humour functions as a social corrective and aims to eliminate the automatic, unquestioning acceptance of the status quo by pointing out its failings and absurdities. The success of the satirist's project thus depends to a great extent on the reader's knowledge of the historical and social context in which the text was composed. The many satirical targets in Candide were therefore made abundantly clear by Voltaire for his contemporary reading public and have subsequently been examined in detail by a vast number of critics. ${ }^{4}$

The focus of this study is therefore not satire per se, which I feel imposes a limitation on the comic genius of Voltaire and on the social and philosophical ramifications of Candide. Underlying the satire of Voltaire's conte is a comic principle which I believe approximates very much to Henri Bergson's theory of comedy and manifests the ethos of Candide in a manner which transcends both the socio-historical context in which the text was composed and the specific targets of his criticism. It expresses Voltaire's deeply humanistic outlook and his abiding concern with what is inimical to the human attainment of happiness.

In Le Rire, his well-known essay on the meaning of comedy, Bergson famously asserts that the comic results from an impression of "raideur de mécanique" (8) or, put more precisely, from a perception of "du mécanique plaqué sur du vivant" (29). In Bergson's view, laughter "châtie les mœurs" (13); it aims to correct certain behaviour regarded as inadmissible by society and to eliminate antisocial eccentricities. Above all, comedy thus expresses "une certaine inadaptation particulière de la personne à la société" (101), and laughter surfaces wherever we apprehend the rigid behaviour which is the sign of an individual's lack of alertness and of his slipping into automatism. This fundamental opposition is further defined by Bergson later on in his seminal study:

Le raide, le tout fait, le mécanique par opposition au souple, au continuellement changeant, au vivant, la distraction par opposition à l'attention, enfin l'automatisme par opposition à l'activité libre, voilà, en somme, ce que le rire souligne et voudrait corriger. (99-100)

This conception of comedy seems to coincide with an essential aspect of Voltaire's thought and determines the targets of much of his satire in Candide. 
A supreme example of this essentially non-satirical comedy can be seen in Candide's protests to Cacambo following their violent arrival in Paraguay. Our hero is insisting that he is unable to eat due to his spiritual torment:

Comment veux-tu, disait Candide, que je mange du jambon, quand j'ai tué le fils de monsieur le baron, et que je me vois condamné à ne revoir la belle Cunégonde de ma vie? à quoi me servira de prolonger mes misérables jours, puisque je dois les traîner loin d'elle dans le remords et le désespoir? et que dira le journal de Trévoux?

En parlant ainsi il ne laissa point de manger. (176)

It is true that there is more than one satirical element in this small excerpt; namely the parody of a sentimental discourse and the reference to the Jesuit Journal de Trévoux. In addition, Voltaire employs the standard comic technique of the debasement of that which is elevated. The rhythm of the passage with the contradiction of its flowing hyperbolic clauses by the abrupt initial period of the succeeding paragraph also contributes to its comic effect. Underlying these details however is the fundamental Bergsonian opposition between the mécanique and the vivant. Bergson observes, "est comique tout incident qui appelle notre attention sur le physique d'une personne alors que le moral est en cause" (39). Since they frequently escape the control of the individual, bodily functions are intrinsically comic. In this instance, Candide is encumbered by the very materiality of his body. Indeed, Bergson makes a particularly apt comment regarding the axiomatic opposition between body and intelligence: " $D$ 'un côté la personnalité morale avec son énergie intelligemment variée, de l'autre le corps stupidement monotone, intervenant et interrompant avec son obstination de machine" (38). Candide's plaintive yet prolix utterance is contradicted by the automatism of his physical gestures. His intellect is effectively overridden by the automatism of his body, and despite his intellectual despair at what has befallen him, his body resolutely manifests an instinctive desire to continue to live. ${ }^{6}$ This opposition between the 'living' and the automatic is reinforced by the stylistic contrast between Candide's expansive outpouring and its debunking by the narrator at the start of the following paragraph. Candide's evocation of the Journal de Trévoux is also evidence of this opposition since it suggests an automatic recourse to authority - in this case, bogus authority, since the Jesuits are 
attacked by Voltaire for their opposition to the Encyclopédistes-as a touchstone for determining action in the real world, and in this respect is akin to the automatism which lies behind the hero's constant referral to the teachings of Pangloss.

Indeed, the clash between intellect and experience is nowhere more apparent than in the character of Pangloss, whose unyielding adherence to Leibinzian Optimism leads to his fulfilling Bergson's three conditions for comedy of character-"l'insociabilité du personnage, l'insensibilité du spectateur... et l'automatisme" (111). The implausibility of the story and the proximity of the characters to marionettes ensures that the reader does not identify with them on an emotional level, and the tenacity of Pangloss's Leibnizian convictions is such that his response to any event is entirely predictable; according to him things could not have been otherwise in this, "le meilleur de tous les mondes possibles" (119). Although he is by no means misanthropic, Pangloss remains somewhat alienated from the other characters by virtue of his inflexible outlook on the world and his intellectual detachment. In Bergson's words he is "un personnage qui suit son idée" (142), who effectively succeeds in extracting himself from reality. It is for unsociability rather than for moral vice that Pangloss is reproached by the reader's laughter. His obstinate adherence to his convictions renders him inflexible and rigid in accordance with Bergson's definition: 'La cause de la raideur par excellence, c'est qu'on néglige de regarder autour de soi: comment modeler sa personne sur celle d'autrui si l'on ne commence par faire connaissance avec les autres et aussi avec soi-même" (112)? At the end of chapter twenty-eight the contrast between the obstinacy and automatism of Pangloss and the experiences he has undergone is comically emphasized:

Eh bien! mon cher Pangloss, lui dit Candide, quand vous avez été pendu, disséqué, roué de coups, et que vous avez ramé aux galères, avez-vous toujours pensé que tout allait le mieux du monde? Je suis toujours de mon premier sentiment, répondit Pangloss; car enfin je suis philosophe, il ne me convient pas de me dédire, Leibnitz ne pouvant avoir tort, et l'harmonie préétablie étant d'ailleurs la plus belle chose au monde, aussi bien que le plein et la matière subtile. (251)

In the gulf which separates Pangloss's Leibnizian convictions from the chaos of the 'real' world we thus encounter another example of the 
"mécanique plaqué sur du vivant." Pangloss here seems to concede the untenability of the philosophy he has espoused (although as Voltaire's satire of a philosopher he is bound to assert its tenets even in the face of evidence to the contrary), and his continued stubborn allegiance to it only serves to underline his automatism. ${ }^{7}$ This attitude is maintained to the very end of the story where the outlooks of all the characters are examined: "Pangloss avouait qu'il avait toujours horriblement souffert; mais ayant soutenu une fois que tout allait à merveille, il le soutenait toujours, et n'en croyait rien" (256). By the end of the story, then, Pangloss seems to have internalized the comic contradiction between the living and the mechanical; instead of being merely at odds with the world, he is also at odds with himself, the automatism of his philosophical side indicated by the verb soutenir, and his living, human side represented by the verb croire. Rhetoric and intellect are once more opposed to lived experience, and although one aspect of Pangloss's character seems to have evolved (he admits the shortcomings of Optimism), his thought nonetheless remains encased in the armour of systematic abstraction. ${ }^{8}$

The comic unsociablility produced by Pangloss's commitment to his philosophy is reinforced by what Bergson terms "l'endurcissement professionnel" (137) or the rigid indifference which results from seeing everything in the terms dictated by one's profession. Such is the strength of the distorting lens through which he views the world that Pangloss the professional philosopher fails to identify with his fellow human beings and remains unmoved at the death of his Dutch benefactor. Candide, on the other hand, is distraught and attempts to rescue the Anabaptist, but "le philosophe Pangloss l'en empêche, en lui prouvant que la rade de Lisbonne avait été formée exprès pour que cet anabaptiste s'y noyât" (134). The unforgiving logic of his profession is thus applied systematically by Pangloss, and the doctrine of finality, which unfailingly provides the philosopher with a specious explanation for the necessity of everything, is a spectacular example of the mécanique plaqué sur du vivant, with the absurd contingencies of life regarded as figuring in a divine teleological plan. At the beginning of the conte, Pangloss assures Candide that "tout étant fait pour une fin, tout est nécessairement pour la meilleure fin. Remarquez bien que les nez ont été faits pour porter des lunettes, aussi avons-nous des lunettes" (119). In "Fin, Causes finales" in his Dictionnaire philosophique, Voltaire himself refutes this proposition, pointing out its absurdity-"tous les nez ne portent pas des lunettes"-and concluding that "il y a donc des effets produits par des causes finales, et des effets en très grand nombre qu'on ne peut appeler de ce nom" (200). In Bergson's 
words, Pangloss tends to "plier les choses à son idée, au lieu de régler sa pensée sur les choses" (142), and it is the consequent absurdity of the latter's assertions which we find comic. ${ }^{9}$

In the course of the narrative, the constant repetition of Pangloss's philosophical tenets, and especially of his conviction that he inhabits "le meilleur des mondes possibles," therefore acquires the resonance of a comic refrain which, whenever encountered, provokes the reader's laughter at the disparity between abstract philosophy and empirical existence. Not only is it reiterated by Pangloss himself; it also issues from other characters, most notably from Candide who had been Pangloss's pupil in Westphalia. The reiteration recalls Bergson's explanation for the comic effect of the jack-in-the-box: "Nous avons tous joue autrefois avec le diable qui sort de sa boîte. On l'aplatit, il se redresse. On le repousse plus bas, il rebondit plus haut" (53). This is in fact the precise role played by Pangloss in both a moral and a physical sense; the narrative is punctuated by his reappearances or, in the case of his absence, by the repetition of his axioms. Bergson himself transfers the physical image of the jack-in-thebox to the moral realm: "Imaginons maintenant un ressort plutôt moral, une idée qui s'exprime encore, un flot de paroles qui s'élance, qu'on arrête et qui repart toujours. Nous avons de nouveau la vision d'une force qui s'obstine et d'un autre entêtement qui la combat" (54). Immobility and repetition, both of which stand in contradiction to the eternal flux of life, thus constitute the essential elements of the confrontation of Pangloss's "force qui s'obstine," his standard, automatic interpretation of all events, with the powerful testimony of experience, or "l'entêtement qui la combat."

If Pangloss's unshakeable philosophical convictions render him the most 'automatic' and therefore, if comedy can be calculated quantitatively, the most comic of the characters in Candide, numerous others also manifest mechanical tendencies and fulfil Bergson's three conditions for the comedy of character. Martin, the Manichean, is a foil to Pangloss in philosophical terms; we might say that he believes the world to be "le pire des mondes possibles." However, despite the opposed interpretations of the world which they both personify, they closely resemble each other in the tenacity of their convictions and their consequent inflexibility. Martin assures Candide that he will never again see his valet, Cacambo, who in fact shows himself entirely worthy of his master's trust. Martin, however, is less comical than Pangloss since his philosophy appears less absurd and unfounded than Optimism; the former's conclusions accord to a greater degree with his own experience and with the nature of the events depicted 
in the narrative. On the other hand, the young Baron Thunder-ten-tronck appears ridiculous because of his obstinate adherence to notions of social class which leads on two occasions to his refusal to consent to the marriage of his sister and Candide in spite of all that the latter has undergone with this one aim in mind. Reunited unexpectedly with the Baron in Paraguay, Candide's articulation of his reasonable wish to marry Cunégonde meets with the following brusque rebuke: "Vous, insolent! ... vous auriez l'impudence d'épouser ma soeur, qui a soixante et douze quartiers! je vous trouve bien effronté d'oser me parler d'un dessin si téméraire" (174). Voltaire here effectively satirizes the pretensions of the nobility, which he shows as resulting in an extreme lack of flexibility and a failure to adapt to changing circumstances. Like Pangloss, whose pride in being a philosopher ensures his comic status, the Baron falls victim to his own aristocratic vanity. Even at the end of the story, despite Cunegonde's ugliness and his own obligations to Candide, the Baron remains intransigent, his rigid perception of the world utterly failing to take account of change. Indeed, his inflexibility is explicitly evoked in the text:

Je ne souffrirai jamais ... une telle bassesse de sa part, et une telle insolence de la vôtre; cette infamie ne me sera jamais reprochée ... Non, jamais ma sœur n'épousera qu'un baron de l'empire. Cunégonde se jeta à ses pieds, et les baigna de larmes; il fut inflexible. (253)

Once more, it is the discrepancy between the repeated fixed idea, the rigidity of the Baron's outlook (who else would want to marry his sister now?) and the flexibility demanded by reality which make us laugh.

This is also true, although to a lesser extent, of Candide himself whose comic fault is his very candour. His naivety costs him dear and contrasts with the bitter cynicism of Martin. Candide's ingenuousness is also evidence of a certain cultural rigidity which affects his perception of reality in foreign environments. Indeed, cultural relativism constituted a pervasive theme in the literature of the period and the benefits of travel are explicitly referred to at several points in the text. ${ }^{10}$ In Eldorado, Candide remarks that "si notre ami Pangloss avait vu Eldorado, il n'aurait pas dit que le château de Thunder-ten-tronckh était ce qu'il y avait de mieux sur la terre; il est certain qu'il faut voyager" (189). However, Candide frequently does not possess sufficient open-mindedness or the adaptability to accommodate the situation at hand. Before falling captive to the Oreillons, Candide and Cacambo wander through a prairie where the former kills two monkeys he 
believes to be molesting two young women. It transpires that the monkeys were the lovers of the two girls and that Candide's cultural inflexibility-his Western European luggage-has led him to make an incorrect appraisal of the situation. Cacambo, the well-travelled product of a mixture of cultures, explains to Candide that values are not universal: "Mon cher maitre . . . vous êtes toujours étonné de tout; pourquoi trouvez-vous si étrange que dans quelques pays il y ait des singes qui obtiennent les bonnes grâces des dames" (177)? However, not even Cacambo's travels have prepared him for the other world of Eldorado where both he and Candide apply German custom to the country where "tout est bien" (151), thereby committing a faux pas which the inhabitants of Eldorado find comic; in this instance intra-textual laughter anticipates and reflects the extra-textual laughter of the reader: "Quand le repas fut fini, Cacambo crut, ainsi que Candide, bien payer son écot en jetant sur la table de l'hôte deux de ces larges pièces d'or qu'il avait ramassées; l'hôte et l'hôtesse éclatèrent de rire, et se tinrent longtemps les côtés" (185-86). Once again, we notice a comic discrepancy between the mentality of an individual and a situation which his cultural and social conditioning does not enable him to grasp in the appropriate manner. Candide's awareness is effectively diminished through his own innate naivety and by his belonging to a particular society which deprives him of what Bergson terms elasticity: "Ce que la vie et la société exigent de chacun de nous, c'est une attention constamment en éveil, qui discerne les contours de la situation présente, c'est aussi une certaine élasticité du corps et de l'esprit, qui nous mette à même de nous y adapter" (14). Most of the characters in Candide lack to some extent the alertness and flexibility deemed essential for life by Bergson.

However, while the Baron's inflexibility is irremediable and combines with his inhumanity to result in his banishment to the galleys, Candide has, by the end of the narrative, rid himself to a certain degree of his comic automatism and evolved into a more adaptable character. Having oscillated in the course of the story between a staunch faith in Pangloss's doctrines-"Tout est bien, tout va bien, tout va le mieux qu'il soit possible" (224)-and a more sceptical approach to the latter's teachings-"il faudra qu'à la fin je renonce à ton optimisme" (196), Candide eventually abandons his mechanical to-ing and fro-ing between opposed philosophies and replaces sterile intellectualism with a much more practical, flexible and pragmatic outlook: "il faut cultiver notre jardin" (260). Revealingly, he replaces an abstract intellectual system with a vital, 'organic' activity and promotes active involvement in, and responsibility for, the shaping of one's life over the passive acceptance of events which is the inevitable 
result of an espousal of Pangloss's doctrines. Instead of merely interpreting the world in the manner of his mentor, Candide seeks to involve himself in it. By the end of the narrative, Candide has thus divested himself of the rigidity of a comic type to don in its stead a more individual and human suppleness.

The mechanical rigidity we have hitherto located in the characters of Candide is likewise present in the text on a structural level. Indeed, the narrative's mechanically repetitive structure, with its inexorable succession of calamities, emphasizes the comic implausibility of the events depicted. The interpolated account by the Vieille of her misfortunes at the hands of fate constitutes a microcosmic reflection of the repetition within the diegesis as a whole: "Un marchand m'acheta, et me mena à Tunis; il me vendit à un autre marchand, qui me revendit à Tripoli; de Tripoli je fus revendue à Alexandrie, d'Alexandrie à Smyrne, de Smyme à Constantinople" (160). We have the impression of a barely-concealed mechanism functioning beneath a semblance of 'reality,' the structure of Candide resulting essentially from the imposition of a repeated action (at its most basic composed of a meeting, a conflict, and a departure) on a far-fetched succession of situations. As we have observed, "est comique tout arrangement d'actes et d'événements qui nous donne, insérés l'un dans l'autre, l'illusion de la vie et la sensation nette d'un agencement mécanique" (53). We have already seen that Bergson regards repetition as symptomatic of a lack of attention to life; he believes the same can be said for coincidences and circularity, arguing that "si les événements pourraient être sans cesse attentifs à leur propre cours, il n'y aurait pas de coincidences, pas de rencontres, pas de séries circulaires; tout se déroulerait en avant et progresserait toujours" (66). Candide finally precipitates an end to the repetitive cycle of the events which structure the narrative at the close of the story. However, this is only achieved after his separation from Pangloss in Germany, his subsequent meeting with him in Portugal, and, after the supposed death of the philosopher who had been hanged as a scapegoat in the wake of the Lisbon earthquake, following a final reunion in a galley bound for Constantinople. Cunégonde and her brother reappear in the course of the narrative in an equally implausible manner. Candide himself comments on the incredible nature of this succession of events after his supper with the six dethroned kings in Venice: "Voilà une aventure bien peu vraisemblable que nous avons eue à Venise. On n'avait jamais vu ni ouï conter que six rois détronés soupassent ensemble au cabaret. Cela n'est pas plus extraordinaire, dit Martin, que la plupart des choses qui nous sont arrivées" (243). In a similar vein, having listened to Cacambo's 
account of his adventures during their separation Candide exclaims, "que d'épouvantables calamités enchaînées les unes aux autres!" (244) as if Voltaire did not have complete faith in the intelligence of his reader to arrive independently at this conclusion, used as he or she is to automatic and unquestioning acceptance of what appears on the printed page, or as if Voltaire wished to exploit the comic effect of a remark which is not worth uttering since its truth is so obvious. Such comments within the text imply the author's awareness of the inevitable artificiality inherent in writing fiction; here it is being taken to extremes for comic effect, with the fictional characters pointing out their own fictitiousness and the implausibility of the events they have experienced.

Present in the structure of the story, the comedy of the mechanical imposed on the living also manifests itself in the language Voltaire employs as narrator and which he ascribes to his characters. Bergson observes that this is because "il y a des formules toutes faites et des phrases stéréotypées. Un personnage qui s'exprimerait toujours dans ce style serait invariablement comique" (85). Pangloss provides us once more with the perfect example of "le comique .. . que le langage crée" (Bergson, 79), since his philosophical rhetoric constantly spills over into and distorts his normal speech. However, this tendency is widespread in Candide. In his description of Pangloss's liaison with Paquette the narrator, deliberately we can presume, employs philosophical terminology for comic effect: "Cunégonde ... vit . . . le docteur Pangloss qui donnait une leçon de physique expérimentale à la femme de chambre de sa mère . . Elle vit clairement la raison suffisante du docteur, les effets et les causes" (120). A remark by Bergson neatly sums up the comedy of this passage: "combien n'a-t-on pas obtenu d'effets risibles en transportant dans ce langage professionnel les idees de la vie commune!" (98). The rigid linguistic formulae of philosophical discourse, just like the precepts they express, become a source of comedy when imposed automatically and inappropriately on everyday speech.

Obviously, this amounts to a form of linguistic satire which complements the thematic satire in Candide. In his expression of surprise at the non-existence of monks in Eldorado, Candide makes an oblique-and probably unconscious, thereby comic-attack on the fanaticism and intolerance of the religious sects of the period: "Quoi! Vous n'avez point de moines qui enseignent, qui disputent, qui gouvernent, qui cabalent, et qui font brûler les gens qui ne sont pas de leur avis" (189)? By virtue of his naiveté, Candide here employs the pedantic rhetorical technique of repetition and enumeration, showing to what extent he has internalized the philosophical and concomitant rhetorical teachings of Pangloss. The irony 
here is that the hero's naivety and automatism, which result in his employment of this rhetorical structure, enclose a subversion of both the rhetorical form itself and the thematic content of his utterance. Candide's innocent observation thus acquires comic overtones through the juxtaposition of abstractions (teach, argue, govern, plot) with real actions (burn). A similar comic effect is produced when Candide meets a defigured Pangloss in Holland: "il s'enquit de la cause et de l'effet, de la raison suffisante qui avaient mis Pangloss dans un si piteux état" (130). Satire and Bergsonian comedy are therefore united linguistically in this aping of philosophical discourse.

Bergson identifies the reason for the comic possibilities of language as its tendency to rigidification: "Si cette vie du langage était complète et parfaite, s'il n'y avait rien en elle de figé, si le langage enfin était un organisme tout à fait unifié, incapable de se scinder en organsimes indépendants, il échapperait au comique" (99). It is precisely this aspect of language which Voltaire exploits in his creation of comic proper nouns"Thunder-ten-tronckh (118); "don Fernando d'Ibaara, y Figueora, y Mascarenes, y Lampourdos, y Souza" (164); "Valdberghoff-tarbikdikdorff" (122)-and terminology-"la métaphysico-théologico cosmolonigologie" (119). The absurdity of the above verbal creations reveals to us the comedy which in fact derives from the combination of familiar and formulaic morphemes with meaningless linguistic elements. Voltaire's creative subversion of familiar formulae by interspersing them with an excessive number of 'alien' formulae draws our attention to the potential rigidity of language and to its capacity for being broken down into isolated units. We are therefore led to acknowledge our own lackadaisical relationship with language, a recognition which results in laughter. Furthermore, Voltaire exacerbates the comic effect of these nouns through satirical exaggeration and repetitive enumeration, as within the name of the governor of Buenos Aires. In Bergson's terms then, Candide manifests "[le comique] que le langage crée" in addition to "[celui] que le langage exprime" (79), and shows us that language, like life itself, can easily slip into unconscious automatism.

I therefore hope to have shown that Candide is permeated structurally, thematically and linguistically by the comedy of the mechanical imposed on the living. It is in their criticism of rigid systematization and unthinking automatism that satire and Bergsonian comedy frequently coincide and reinforce each other in Voltaire's story, since the targets of the author's satire are so often guilty of a profound deficiency in the flexibility and alertness which Bergson sees as so essential to life. We find mechanical characters such as Pangloss and the Baron comic for two related rea- 
sons; firstly because, in accordance with Bergson's precepts, they seem to us rigid and inhuman; secondly because we realise that this rigidity originates in absurdities specific to Voltaire's time (but for which, unfortunately, many analogues can be found in our own). In his article, "Le dernier des écrivains heureux," Roland Barthes makes the pertinent observation that Voltaire's enemies are distinguished by the fact that each camp can be identified by a single adjective, such is its rigidity: "c'était de grands corps figés, vidés de toute intelligence, pleins seulement d'une philosophie intolérable pour le cour et 1 'esprit .. . Il suffisait de promener au milieu de cette mécanique le regard d'un homme pour qu'il[s] s'ecroul[assent]" (96). We might relate this Bergsonian remark by Barthes to Bergson's assertion in Les Deux sources de la morale et de la religion that a closed society is one whose members are united in their indifference to the rest of mankind and always ready to defend themselves or to attack (1201). Micosocieties such as the religious sects portrayed in Candide damage sociability, and "le rire a justement pour fonction de réprimer les tendances séparatistes. Son rôle est de corriger la raideur en souplesse, de réadapter chacun à tous, enfin d'arrondir les angles" (135). Voltaire's treatment of humanity's foibles in Candide therefore seems to approximate to Bergson's theories on the comedy of the mechanical through his (systematic!) attacks on the rigid systems-religious, philosophical and social-which prevent men from attaining fulfilment and happiness. In Le Rire Bergson explains that "toute raideur de caractère, de l'esprit et même du corps, sera donc suspecte à la société parce qu'elle est le signe d'un esprit qui s'endort et aussi d'une activité qui s'isole, qui tend à s'écarter du centre commun autour duquel la société gravite" (15). The centre commun of the society promoted by Voltaire consists of tolerance and freedom. Mechanical rigidity therefore amounts to inhuman dogmatism and intolerance, both of which come under the merciless fire of Voltaire's ridicule in Candide. In the article entitled "Tolerance" in his Dictionnaire philosophique, Voltaire makes the connection between the instability and flux inherent to the human condition (what we might approximate to Bergson's 'living') and the necessity for tolerance: "Nous devons nous tolérer mutuellement, parce que nous sommes tous faibles, inconséquents, sujets à la mutabilité, à l'erreur' (407). This is why, to express Voltaire's view in Bergson's terms, we should strive to detach the mechanical from the living or "déplaquer le mécanique du vivant." 


\section{Notes}

1. All quotations from Candide are taken from the edition by René Pomeau (Oxford: The Voltaire Foundation, 1980).

2. An overview of comedy in Voltaire's work is provided by Le Rire de Candide and also discussed in Jean Sareil's Essai sur Candide.

3. Bergson places a disclaimer to this effect at the beginning of $L e$ Rire: "Nous ne viserons pas à enfermer la fantaisie comique dans une définition. Nous voyons en elle, avant tout, quelque chose de vivant" (1). It might also seem somewhat paradoxical to approach the work of one of the bright lights of the Age of Reason through that of the proponent of intuition....

4. Thanks to a number of well-annotated editions of the text (c.f., André Morize (Paris, 1957)), Christopher Thacker (Geneva, 1968) and numerous studies devoted to the subject (c.f., Le Rire de Candide), today's readers cannot but be familiar with the nature of the targets of Voltaire's satire. Here is therefore not the place for their enumeration.

5. All quotations from Le Rire refer to the 123 rd edition by Presses Universitaires Françaises, (Paris, 1958). Page numbers for other works by Bergson refer to the edition of his Euvres by André Robinet (Paris: P.U.F., 1959).

6. We might refer to the experiences of the Vieille at this juncture since she too, although more consistently so than Candide, seems to exhibit what Bergson terms the "élan vital." Recounting her hardships to Candide and Cunegonde during their transatlantic voyage, she touches on an issue which lies at the heart of Voltaire's narrative; namely the intellectual temptation to suicide and our instinctive clinging to life in spite of the trials to which it subjects us:

je voulus cent fois me tuer mais j'aimais encore la vie.

Cette faiblesse ridicule est peut-être un de nos penchants les plus funestes: car y a-t-il rien de plus sot que de vouloir porter continuellement un fardeau qu'on veut toujours jeter par terre? d'avoir son être en horreur, et de tenir à son être? enfin de caresser le serpent qui nous dévore, jusqu'à ce qu'il nous ait mangé le cœur? (162)

7. Bergson's cynicism with regard to philosphical systems is revealed in L'énergie spirituelle: "On ne s'expliquerait pas l'attachement de tel ou tel philosophe a une methode aussi étrange si elle n'avait le triple avantage de flatter son amour propre, de faciliter son travail, et de lui donner l'illusion de la connaissance définitive" (816). In L'évolution 
créatrice Bergson attacks systematization: "L'histoire de la philosophie est la cependant qui nous montre l'éternel conflit des systèmes, l'impossibilité de faire entrer définitivement le réel dans ces vêtements de confection que sont nos concepts tout faits, la nécessité de travailler sur mesure" (535).

8. In Bergson's terms, Pangloss is devoid of "bon sens," which is "l'effort d'un esprit qui s'adapte et se réadapte sans cesse changeant d'idée quand il change d'objet. C'est une mobilité de l'intelligence qui se règle exactement sur la mobilité des choses. C'est la continuité mouvante de notre attention à la vie" (140).

9. Examples of absurd causal chains being taken to extremes (these might also be related to the pervasive theme of genealogy in the story) include Pangloss's explanation of the origin of his syphilis (chapter 4), and of the necessity of everything they have experienced (chapter 30 ). Bergson criticizes finality in $L$ 'évolution créatrice, revealingly invoking Leibniz: "La doctrine de la finalité, sous sa forme extrême, telle que nous la trouvons chez Leibniz par exemple, implique que les choses ne font que réaliser un programme une fois tracé. Mais, s'il nly rien d'imprévu, point d'invention ou de création dans l'univers, le temps devient encore inutile" (528). In "Fin, Causes finales" in his Dictionnaire philosophique, Voltaire makes the point that intelligence and creation on the part of man supplement the final causes instituted by God. Noses are made for smelling, but man's ingenuity has led to their being used to support spectacles (200). Voltaire seems to anticipate Bergson's exaltation of human creativity: "Mais si, après bien des siècles, nous nous sommes avisés d'inventer des ciseaux et des broches, de tondre avec les uns la laine des moutons et de les faire cuire avec les autres pour les manger, que peut-on en infërer autre chose sinon que Dieu nous a faits de façon qu'un jour nous deviendrions nécessairement industrieux et carnassiers" (201)?

10. Of course, the most famous example of this eighteenth century interest is Montesquieu's Lettres persanes. 


\section{Works Cited}

Barthes, Roland. "Le dernier des écrivains heureux." Essais critiques. Paris: Seuil, 1964.

Bergson, Henri. Le Rire: Essai sur la signification du comique. 123rd ed. Paris: P.U.F., 1958.

-. L'Evolution créatrice. Cuvres. Ed. André Robinet. Paris: P.U.F., 1959. -. L'Energie spirituelle. Euvres. Ed. André Robinet. Paris: P.U.F., 1959. - Les deux sources de la morale et de la religion. Euvres. Ed. André Robinet. Paris: P.U.F., 1959.

Sareil, Jean. Essai sur Candide. Geneva: Droz, 1967.

Voltaire. Candide ou l'optimisme. Ed. René Pomeau. Vol. 48. Oxford: The Voltaire Foundation at the Taylor Institution, 1980.

-. Dictionnaire philosophique. Paris: Garnier, 1967. 


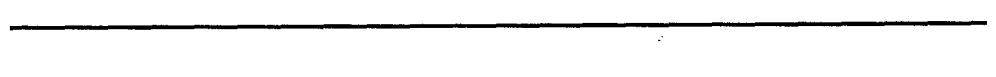

